\title{
PENERAPAN KONSEP PARIWISATA HALAL PADA CITRA MEREK PULAU LOMBOK
}

\author{
Lalu Ferdi Ferdiansyah', Sulhaini ${ }^{2}$, Handry Sudiartha Athar ${ }^{3}$ \\ ${ }_{1}^{1}$ Program Studi Magister Manajemen, Fakultas Ekonomi dan Bisnis Unram \\ E-mail: ferdiferdiansyahlalu@gmail.com \\ 2Fakultas Ekonomi dan Bisnis, Universitas Mataram \\ E-mail: sulhaini@unram.ac.id \\ ${ }^{3}$ Fakultas Ekonomi dan Bisnis, Universitas Mataram \\ handrysudiartha@gmail.com
}

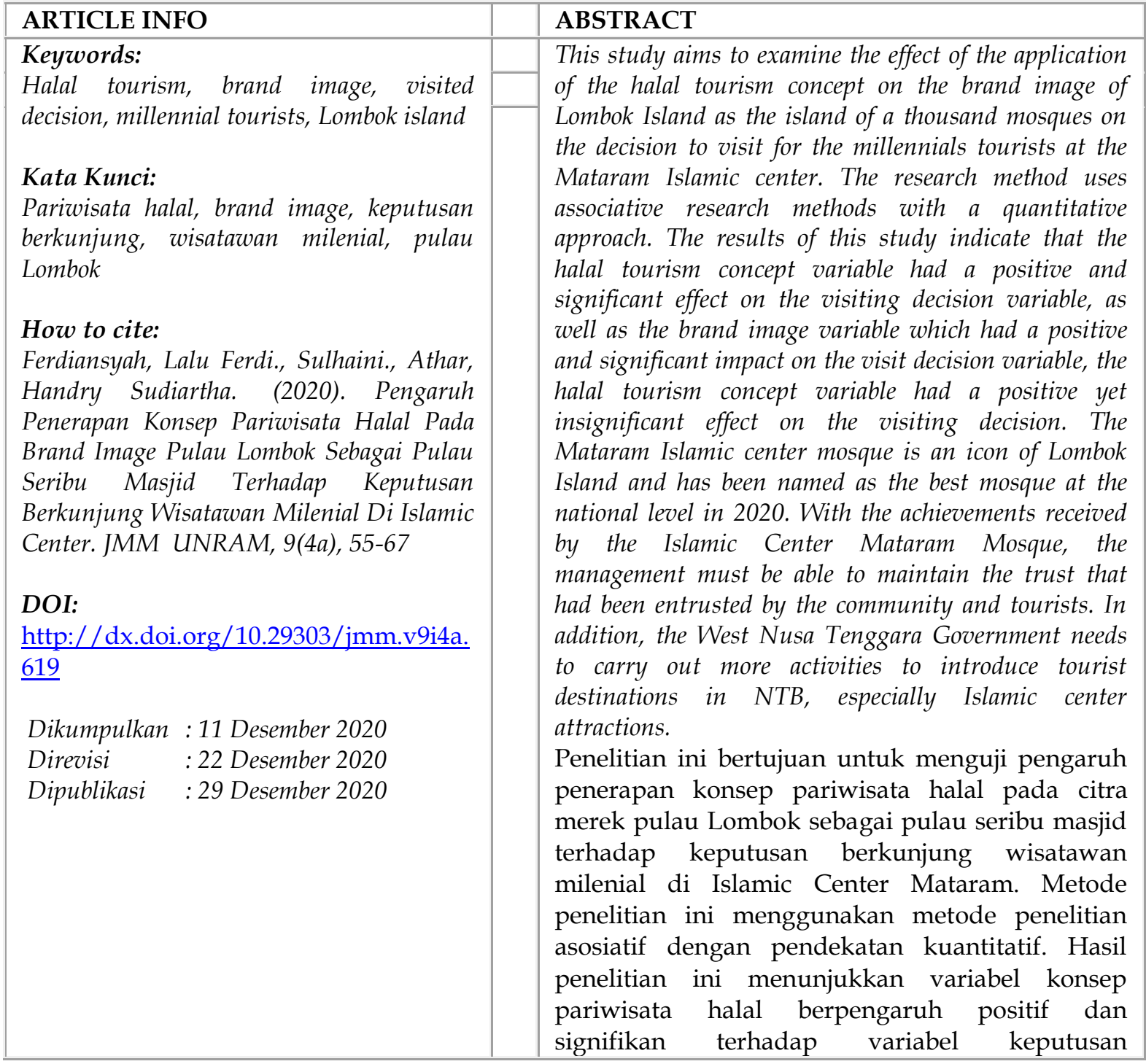




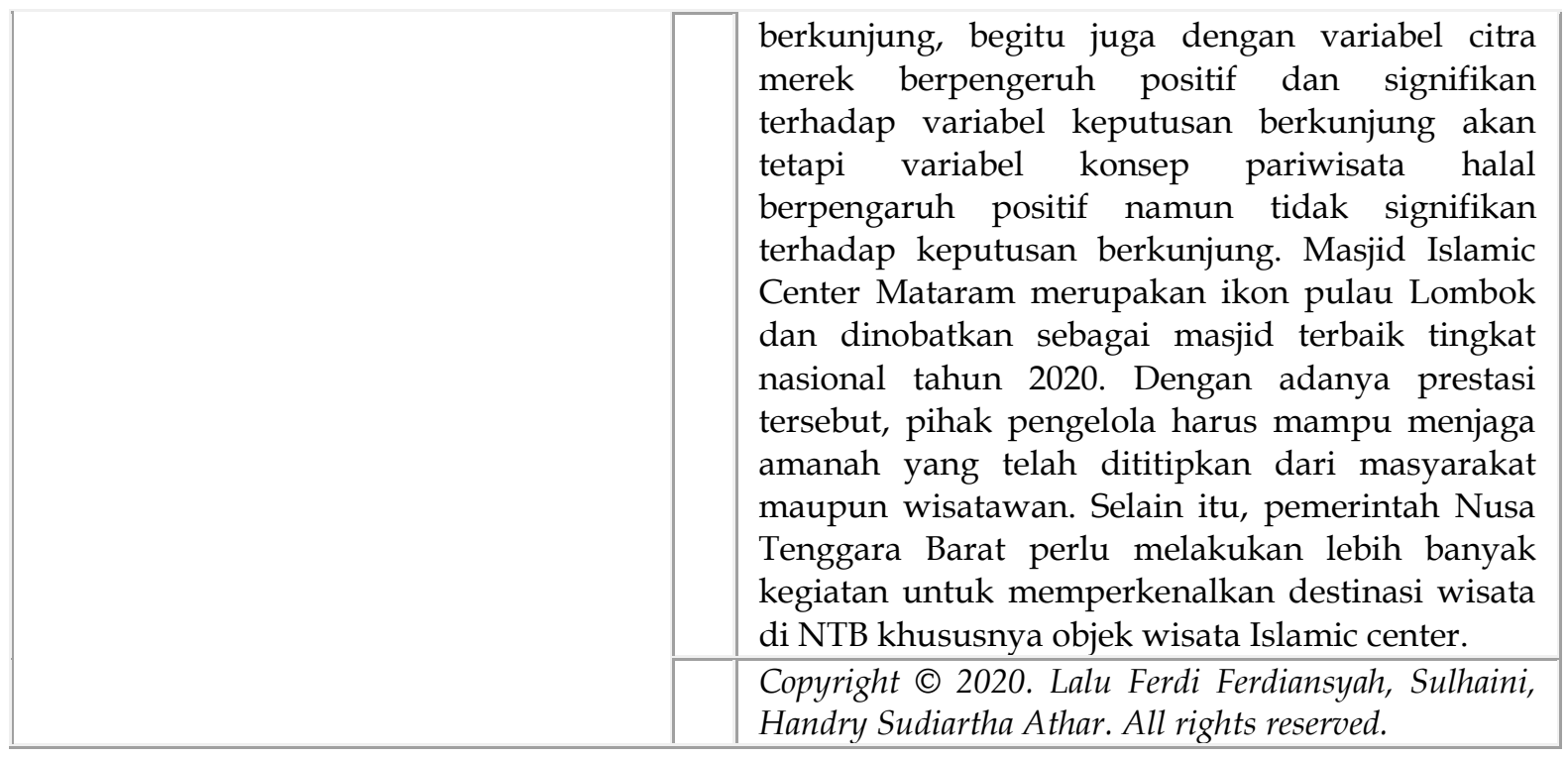

\section{PENDAHULUAN}

Perkembangan pariwisata di Indonesia sekarang ini semakin pesat. Pariwisata merupakan sektor yang sangat menjanjikan dan memberikan manfaat kepada banyak pihak seperti pemerintah, masyarakat maupun swasta. Hal ini dikarenakan pariwisata merupakan sektor yang dianggap menguntungkan untuk dikembangkan sebagai salah satu aset yang digunakan sebagai sumber pendapatan pemerintah maupun masyarakat sekitar objek wisata.

Salah satu pulau di Indonesia yang dapat diandalkan dari sektor pariwisata adalah pulau Lombok, baik dari segi keindahan alam, pegunungan, pantai dll. Hal tersebut dapat dijadikan objek wisata yang tidak kalah saing dengan pulau lain yang ada di Indonesia. Pemerintah telah menerapkan produk baru dalam perindustrian pariwisata yaitu pariwisata halal (halal tourism), mengingat pulau Lombok dengan penduduk mayoritas muslim dan halal branding yang dimilikinya. Ini bisa menjadi nilai kekhasan pulau Lombok yang membedakan destinasi wisata ini dengan destinasi lainnya di Indonesia.

Pulau yang sudah memiliki branding atau merek akan memiliki citra tersendiri bagi wisatawan karena memiliki ciri khas yang membedakan dengan pulau-pulau lain sehingga memberikan kenangan yang berbeda. Penelitian yang dilakukan Nasrullah dan Ardelia (2015) menyimpulkan bahwa adanya pengaruh signifikan antara Islamic branding terhadap keputusan berkunjung. Menurut Fransisca (2019), karakter tempat tujuan wisata dan daya tarik merek berpengaruh berpengaruh terhadap keputusan berkunjung wisatawan milenial ke pulau Lombok.

Persaingan dalam industri pariwisata dan adanya konsep baru membuat banyak negara mayoritas non muslim pun ikut menerapkan konsep pariwisata halal. Mengingat penduduk mayoritas muslim, sudah seharusnya Indonesia khususnya pulau Lombok dengan halal branding yang dimilikinya perlu adanya penelitian terkait penerapan konsep pariwisata halal pada citra merek pulau Lombok sebagai pulau seribu masjid terhadap keputusan berkunjung wisatawan milenial di Islamic Center Mataram. Mohsin dkk, (2016) dan Djakfar (2019) berpendapat bahwa penelitian terkait penerapan konsep pariwisata halal di negara dengan mayoritas muslim masih terbilang sedikit. Oleh karena itu, penelitian ini bertujuan untuk mengetahui seberapa besar pengaruh konsep pariwisata 
halal pada citra merek pulau Lombok terhadap keputusan berkunjung di Islamic Center Mataram.

\section{KAJIAN LITERATUR}

\subsection{Konsep pariwisata halal}

Pariwisata halal merupakan produk yang relatif baru di industri pariwisata yang diarahkan terhadap keluarga muslim yang mematuhi aturan Islam (Gabdrakhmanov dan Rubstov, 2015). Menurut Battour dan Ismail (2016) mengatakan bahwa pariwisata halal adalah "obyek wisata atau kegiatan wisata apapun yang diperbolehkan dalam ajaran Islam untuk dipergunakan atau melibatkan umat muslim dalam kaitannya industry pariwisata". Selain itu Chookaew et al., (2015) mengatakan bahwa konsep wisata halal merupakan aktualisasi dari konsep ke-Islaman yakni nilai halal dan haram menjadi tolak ukur utamanya. Hal ini berarti seluruh aspek kegiatan wisata tidak terlepas dari sertifikasi halal yang harus menjadi acuan bagi setiap pelaku pariwisata.

\subsection{Brand image (Citra merek)}

Menurut Kotler (2007) citra merek adalah seperangkat keyakinan, ide, kesan yang dimiliki seseorang terhadap suatu merek, karena itu sikap dan tindakan konsumen terhadap suatu merek sangat ditentukan citra merek tersebut. Citra merek merupakan janji penjual untuk secara konsisten memberikan feature, manfaat dan jasa tertentu kepada pembeli bukan hanya sekedar symbol yang membedakan produk perusahaan tertentu dengan kompetitornya. Schifmann dan Kanuk (2007) berpendapat bahwa citra merek adalah sekumpulan asosiasi mengenai suatu merek yang tersimpan dalam benak atau ingatan konsumen. Sedangkan Supranto (2011:128) mengatakan bahwa citra merek adalah apa yang konsumen pikir atau rasakan ketika mereka mendengar atau melihat nama suatu merek atau pada intinya apa yang telah konsumen telah pelajari tentang citra merek.

\subsection{Keputusan berkunjung}

Pengambilan keputusan dapat dianggap sebagai kegiatan konsumen memilih suatu produk atau jasa dalam melakukan keputusan pembelian (Kotler dan Amstrong, 2003:224). Proses pengambilan keputusan ini sangat penting bagi pembangunan pariwisata terkait dengan berbagai fakta yang mempengaruhi keputusan berkunjung ke suatu destinasi wisata. Selain itu Peter dan Olson (2013:163) menyebutkan bahwa pengambilan keputusan konsumen adalah proses integrasi yang digunakan untuk mengkombinasikan pengetahuan untuk mengevaluasi dua atau lebih perilaku alternative dan memilih satu diantaranya. Tjiptono, 2001:22 dalam Trista dkk, 2012 juga menyebutkan bahwa keputusan pembelian adalah perilaku konsumen setelah memperoleh informasi mengenai sebuah produk yang diinginkan serta proses penilaian dan pengambilan keputusan dengan menetapkan satu pilihan yang dianggap paling menguntungkan.

\subsection{Hubungan antar variabel}

\section{Hubungan antara konsep pariwisata halal dan citra merek}

Penerapan konsep pariwisata halal terhadap suatu pulau dengan mayoritas muslim akan berpengaruh terhadap citra merek. Karena tidak menutup kemungkinan bahwa wisatawan yang mengunjungi daerah tersebut melihat profil dari pulau itu sendiri untuk dikunjungi. Berdasarkan hasil penelitian yang dilakukan oleh Haidar (2018), menujukkan bahwa adanya korelasi yang signifikan dan positif antara konsep pariwisata halal terhadap citra merek pulau dengan mayoritas muslim. Sudigdo (2018) juga 
melakukan penelitian yang sama dengan menunjukkan hasil bahwa variabel konsep pariwisata halal berpengaruh terhadap citra merek destinasi. Selain itu, penelitian yang dilakukan oleh Kurniawati (2019) menunjukkan bahwa variabel konsep pariwisata halal berpengaruh terhadap citra merek.

H1 : Konsep pariwisata halal berpengaruh signifikan pada citra merek dalam meningkatkan kunjungan wisatawan.

Hubungan antara citra merek dan keputusan berkunjung

Penerapan island branding pada suatu destinasi wisata akan berpengaruh terhadap keputusan wisatawan untuk mengunjungi suatu obyek wisata di daerah tersebut. Pulau yang sudah memiliki branding atau merek akan memiliki citra tersendiri bagi wisatawan karena memiliki ciri khas yang membedakan dengan pulau-pulau lain sehingga memberikan kenangan yang berbeda. Berdasarkan penelitian yang dilakukan oleh Purwanto dan Soliha (2017) menunjukkan bahwa citra merek mempunyai pengaruh yang signifikan terhadap keputusan berkunjung. Selain itu, penelitian yang dilakukan oleh Arif dan Gunadi (2018) juga menunjukkan hal yang sama, bahwa brand mage berpengaruh signifikan terhadap keputusan berkunjung. Penelitian yang dilakukan oleh Fitriana (2019) pun menunjukkan hasil yang sama bahwa citra merek memiliki pengaruh yang positif dan signifikan terhadap keputusan berkunjung.

Adanya branding pada suatu pulau memiliki tujuan untuk meningkatkan kunjungan wisatawan terhadap obyek wisata yang ada. Ketika citra merek sudah terbentuk di suatu pulau diharapkan mampu menjadikan daerah tersebut sebagai daerah tujuan wisata.

H2 : Citra merek berpengaruh signifikan pada keputusan berkunjung.

\section{Hubungan antara pariwisata halal dan keputusan berkunjung}

Menurut (Mohsin dkk: 2016) mengatakan bahwa pariwisata halal mengacu pada penyediaan produk dan layanan pariwisata yang memenuhi kebutuhan pelancong muslim untuk memenuhi fasilitas ibadah dan persyaratan lain yang sesuai dengan ajaran Islam. Selain itu menurut (Adinugraha dkk: 2018, 33) konsep pariwisata halal (wisata syariah) adalah proses pengintegrasian nilai-nilai keIslaman kedalam seluruh aspek kegiatan wisata. Berdasarkan penelitian sebelumnya Safira et al (2019) menunjukkan bahwa variabel konsep pariwisata halal mempunyai pengaruh signifikan terhadap keputusan berkunjung. Muharromah dan Anwar (2020) juga melakukan penelitian yang menunjukkan hasil bahwa variabel konsep pariwisata halal mempunyai pengaruh positif dan signifikan terhadap keputusan berkunjung. Penerapan konsep pariwisata halal di pulau Lombok akan berpengaruh pada keputusan berkunjung. Hal ini tidak terlepas dari mayoritas penduduk muslim dan citra merek yang dimiliki pulau Lombok yang lebih dikenal dengan pulau seribu masjid. 
H3 : Penerapan konsep pariwisata halal di pulau dengan mayoritas muslim akan berpengeruh terhadap keputusan berkunjung.

Gambar 1. Kerangka konseptual penelitian

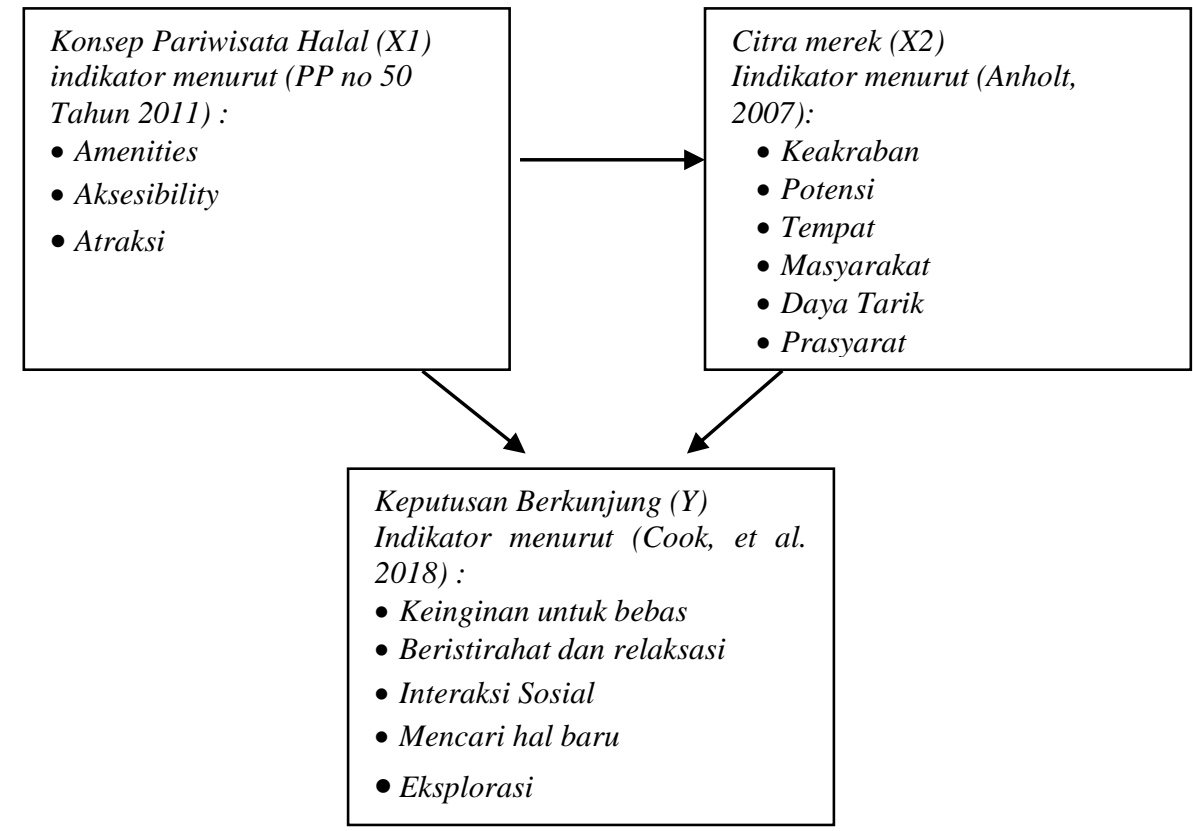

\section{METODE PENELITIAN}

Penelitian ini menggunakan metode kuantitatif dengan pendekatan asosiatif.Populasi dalam penelitian ini adalah wisatawan milenial yang berkunjung di Masjid Islamic Center Mataram.Teknik penentuan sampel yang dilakukan dalam penelitian ini bersifat tidak acak (non random sampling) dengan menggunakan teknik purposive sampling. Karakteristik responden dalam penelitian ini adalah wisatawan milenial dengan kisaran usia 16 hingga 30 tahun. Teknik analisis data pada penelitian ini adalah regresi linier berganda.Data dianalisis menggunakan SPSS (Statistic Package for the Social Science). Dari hasil olah data, karakteristik responden berdasarkan jenis kelamin dalam penelitian ini ditemukan laki-laki sebanyak 46 orang atau sebesar $65,7 \%$ dan perempuan sebanyak 24 orang atau sebesar 34,3\%. Karakteristik responden berdasarkan usia kurang dari 25 tahun sebanyak 59 orang atau sebesar 84,3\% dan antara 26-30 tahun sebanyak 11 orang atau sebesar 15,7 .

\subsection{Uji Instrumen}

Instrument dalam penelitian ini menggunakan instrument penelitian berupa kuesioner dengan 38 item pertanyaan.Pertanyaan tersebut menerangkan 3 variabel yang diteliti dalam penelitian ini.Pengukuran variabel konsep pariwisata halal dan indikator pada penelitian ini mengacu pada PP No 50 tahun 2011.Indikator brand image pada penelitian ini mengacu pada Anholt (2007).Sedangkan indikator keputusan berkunjung pada penelitian ini mengacu pada Cook et al. 2008. Adapun perhitungan uji validitas terhadap data kuesioner dapat dilihat pada tabelberikut: 


\section{Tabel 1. Uji validitas}

\begin{tabular}{|c|c|c|c|}
\hline No & Pernyataan & r hitung & r tabel \\
\hline \multicolumn{4}{|c|}{ A. Konsep wisata halal (amenities - fasilitas/sarana pendukung) } \\
\hline 1 & Sarana ibadah yang disediakan memadai & 0,533 & 0,235 \\
\hline 2 & Kondisi sarana ibadah yang baik & 0,394 & 0,235 \\
\hline 3 & Toiletris / Perlengkapan mandi tersedia & 0,267 & 0,235 \\
\hline 4 & Terdapat toilet yng terpisah antara lali-laki dan perempuan & 0,462 & 0,235 \\
\hline 5 & Jumlah toilet memadai & 0,518 & 0,235 \\
\hline 6 & Tersedia lahan parkir untuk kendaraan wisatawan & 0,373 & 0,235 \\
\hline 7 & Luas lahan parkir memadai & 0,339 & 0,235 \\
\hline 8 & Terdapat staf dan penjaga keamanan di area Masjid Islamic center & 0,482 & 0,235 \\
\hline 9 & Keamanan parkir terjamin & 0,637 & 0,235 \\
\hline 10 & Terdapat penunjuk arah di sekitar area Masjid Islamic center & 0,624 & 0,235 \\
\hline 11 & Terdapat warung di sekitar Masjid Islamic center & 0,350 & 0,235 \\
\hline 12 & Harga makanan terjangkau & 0,517 & 0,235 \\
\hline 13 & Kondisi jalan menuju obyek wisata baik (beraspal) & 0,493 & 0,235 \\
\hline & $\begin{array}{l}\text { Tidak ada hambatan lalu lintas menuju obyek wisata (Masjid } \\
\text { Islamic center) }\end{array}$ & 0,564 & 0,235 \\
\hline & $\begin{array}{l}\text { Terdapat rambu-rambu lalu lintas menuju obyek wisata (Masjid } \\
\text { Islamic center) }\end{array}$ & 0,520 & 0,235 \\
\hline & $\begin{array}{l}\text { Terdapat papan penunjuk jalan menuju obyek wisata (Masjid } \\
\text { Islamic center) }\end{array}$ & 0,618 & 0,235 \\
\hline & $\begin{array}{l}\text { Terdapat transportasi umum menuju obyek wisata (Masjid Islamic } \\
\text { center) }\end{array}$ & 0,547 & 0,235 \\
\hline \multicolumn{4}{|c|}{ Atraksi wisata/atraksi budaya yang mencerminkan pulau Lombok } \\
\hline & $\begin{array}{l}\text { Saya merasa aman mengunjungi obyek wisata (Masjid Islamic } \\
\text { center) }\end{array}$ & 0,606 & 0,235 \\
\hline & $\begin{array}{lcccc}\begin{array}{l}\text { Masyarakat } \\
\text { berkomunikasi/berinteraksi }\end{array} & \text { serta } & \text { mudah } & \text { dalam } \\
\end{array}$ & 0,633 & 0,235 \\
\hline & $\begin{array}{l}\text { Terdapat informasi mengenai niliai historis, sejarah peradaban } \\
\text { Islam di Lombok. }\end{array}$ & 0,470 & 0,235 \\
\hline
\end{tabular}

B. Brand image pulau Lombok (Pulau seribu masjid)

\begin{tabular}{llcc}
\hline Keakraban (Presence) & & \\
\hline 21 & Masjid Islamic center merupakan icon pulau Lombok & 0,634 & 0,235 \\
\hline 22 & Pulau Lombok merupakan pulau seribu masjid & 0,481 & 0,235 \\
\hline & Potensi (Potencial) & & \\
\hline 23 & Pengelolan Masjid Islamic center dilakukan dengan baik dan benar & 0,613 & 0,235
\end{tabular}


Lanjutan tabel 1

\begin{tabular}{|c|c|c|c|}
\hline 24 & $\begin{array}{l}\text { Dengan adanya Masjid Islamic center dapat meningkatkan } \\
\text { Perekonomian masyarakat sekitar }\end{array}$ & 0,611 & 0,235 \\
\hline & Tempat (Place) & & \\
\hline 25 & Aspek fisik bangunan dan penataan Masjid Islamic center baik & 0,627 & 0,235 \\
\hline \multirow[t]{2}{*}{26} & Letak bangunan Masjid Islamic center strategis & 0,523 & 0,235 \\
\hline & Masyarakat (People) & & \\
\hline 27 & Masyarakat di pulau Lombok ramah, sopan dan santun & 0,701 & 0,235 \\
\hline \multirow[t]{2}{*}{28} & $\begin{array}{l}\begin{array}{l}\text { Masyarakat di pulau Lombok mudah di ajak dalam } \\
\text { bergaul/berinteraksi }\end{array} \\
\end{array}$ & 0,577 & 0,235 \\
\hline & Daya tarik (Pulse) & & \\
\hline \multirow[t]{2}{*}{29} & $\begin{array}{l}\text { Bangunan Masjid Islamic center mencerminkan branding pulau } \\
\text { Lombok }\end{array}$ & 0,688 & 0,235 \\
\hline & Prasyarat (Prerequistie) & & \\
\hline 30 & Terdapat transportasi menuju Masjid Islamic center & 0,533 & 0,235 \\
\hline 31 & Terdapat penginapan di sekitar Masjid Islamic center & 0,434 & 0,235 \\
\hline 32 & Tersedianya peralatan ibadah yang lengkap & 0,522 & 0,235 \\
\hline \multicolumn{4}{|c|}{ C. Keputusan berkunjung } \\
\hline 33 & $\begin{array}{l}\text { Saya mengunjungi pulau Lombok karena adanya keinginan untuk } \\
\text { bebas/bebas. }\end{array}$ & 0,540 & 0,235 \\
\hline 34 & Saya mengunjungi pulau Lombok untuk mencari hal yang baru. & 0,662 & 0,235 \\
\hline 35 & Saya mengunjungi pulau Lombok untuk berpetualang. & 0,644 & 0,235 \\
\hline 36 & $\begin{array}{l}\text { Saya mengunjungi pulau Lombok untuk mengeksplorasi (mencari } \\
\text { informasi). }\end{array}$ & 0,664 & 0,235 \\
\hline 37 & $\begin{array}{l}\text { Saya mengunjungi pulau Lombok karena banyaknya media yang } \\
\text { meliput berita tentang pulau Lombok. }\end{array}$ & 0,681 & 0,235 \\
\hline 38 & $\begin{array}{l}\text { Saya mengunjungi pulau Lombok karena indahnya pesona alam } \\
\text { ciptaan Tuhan }\end{array}$ & 0,435 & 0,235 \\
\hline
\end{tabular}

Sumber: Data primer diolah, 2020

Dari hasil uji validitas tersebut, nilai $\mathrm{r}$ hitung pada setiap item pernyataan lebih besar dari nilai $r$ tabel yaitu 0.235 , sehingga dari hasil uji tersebut semua item pernyataan instrumen penelitian ini dinyatakan valid dan layak digunakan ke tahap selanjutnya. Adapun hasil uji reliabilitas adalah pada kuesioner dapat dilihat pada tabel 2berikut :

Tabel 2. Uji reliabilitas

\begin{tabular}{lc}
\hline \multicolumn{1}{c}{ Variabel } & $\begin{array}{c}\text { Cronbach } \\
\text { Alpha }\end{array}$ \\
\hline Konsep Pariwisata Halal (X1) & 0.881 \\
\hline Brand Image (X2) & 0.879 \\
\hline Keputusan Berkunjung (Y) & 0.828 \\
\hline Sumber: Data primer diolah, 2020 &
\end{tabular}

Berdasarkan hasil uji reliabilitas yang telah dilakukan, nilai Cronbach alpha keseluruhan variabellebih dari nilai Cronbach Alpha 0.70.Sehingga dapat disimpulkan bahwa semua variabel instrumen penelitian adalah reliabel. 


\subsection{Uji Normalitas}

Untuk mengurangi tingkat data error, pada penelitian ini dilakukan beberapa uji asumsi klasik diantaranya uji normalitas, uji multikolinieritas dan uji linieritas.Uji normalitas digunakan untuk mengetahui apakah sampel yang diambil berasal dari populasi yang berdistribusi normal atau tidak.Untuk menguji normalitas maka teknik yang digunakan yaitu dengan uji kolmogorov-smirnov. Kriteria pengujian kolmogorov smirnov yaitu sampel berasal dari populasi yang berdistribusi normal apabila nilai sig. (signifikansi) pada tiap-tiap variabel $\geq 0,05$ dan sampel berasal dari populasi yang tidak berdistribusi normal apabila nilai sig. (signifikansi) pada tiap-tiap variabel $<0,05$. Hasil uji kolmogrovsmirnov menunjukkan bahwa nilaip (asyp.sig) pada setiap variabel lebih besar dari cut off (a) sebesar 0.05. Sehingga dapat disimpulkan bahwa didistribusi nilai residual regresi memenuhi uji normalitas.

\subsection{Uji Multikolinieritas}

Uji multikolinieritas dimaksudkan untuk mengetahui ada tidaknya multikolinieritas antara variabel bebas. Multikolinieritas tidak terjadi apabila nilai toleransi lebih dari 0,1 dan nilai VIF (variance inflation faktor) kurang dari 10. Berdasarkan hasil multikolinieritas antara variabel menunjukkan bahwa korelasi antar variabel bebas mempunyai nilai toleransi lebih dari 0,1 yaitu konsep pariwisata halal (X1) sebesar 0,357; brand imgage (X2) sebesar 0,357. Sedangkan untuk nilai VIF kurang dari 10 yaitu konsep pariwisata halal (X1) sebesar 1,000; brand image (X2) sebesar 1,000. Model regresi yang baik adalah yang tidak mengandung masalah multikolinieritas.

\subsection{UjiLinieritas}

Uji linieritas bertujuan untuk mengetahui apakah dua variabel mempunyai hubungan yang linier atau tidak secara signifikan.Kriteria yang berlaku adalah jika nilai signifikansi pada linearity $\leq 0,05$, maka dapat diartikan bahwa antara variabel bebas dan terikat memiliki hubungan linieritas. Berdsarkan hasil olah data tersebut, signifikansi linearity antar variabel kurang dari 0,05 artinya bahwa terdapat linieritas antara kedua variabel baik dependen maupun independent.

\section{HASIL DAN PEMBAHASAN}

\subsection{Statistik deskriptif}

Pada penelitian ini diperoleh hasil analisis statistic deskriptif yang ditampilkan pada tabel 3berikut:

Tabel 3. Tabel statistik deskriptif

\begin{tabular}{clcccc}
\hline No & \multicolumn{1}{c}{ Variabel } & $\begin{array}{c}\text { Nilai } \\
\text { Minimum }\end{array}$ & $\begin{array}{c}\text { Nilai } \\
\text { Maksimum }\end{array}$ & $\begin{array}{c}\text { Rata-Rata } \\
\text { Total }\end{array}$ & Kategori \\
\hline 1 & Konsep pariwisata halal & 3,64 & 4,61 & 4,11 & sangat baik \\
\hline 2 & Brand image & 3,64 & 4,60 & 4,09 & sangat baik \\
\hline 3 & Keputusan berkunjung & 3,13 & 4,23 & 3,59 & sangat baik \\
\hline
\end{tabular}

Sumber: Data primer diolah, 2020

Dari tabel 3 diatas bahwa rata-rata total variabel untuk konsep pariwisata halal sebesar 4,11 dengan kategori sangat baik artinya dapat disimpulkan bahwa konsep wisata yang disesuaikan dengan prinsip syariah yaitu prinsip-prinsip ajaran Islam sangat baik dari segi amenities (fasilitas/sarana pendukung), aksesibility (sarana menuju objek wisata Islamic center) dan atraksi (atraksi wisata) sudah baik menurut para wisatawan. Untuk variabel brand image rata-rata total sebesar 4,09 dengan kategori sangat baik artinya ini 
menunjukkan bahwa persepsi yang dimiliki/diingat oleh wisatwan terhadap pulau Lombok sebagai pulau seribu masjid adalah tinggi. Hal ini juga menunjukkan bahwa pulau Lombok memang dikenal/mencerminkan pulau dengan seribu masjid. Kemudian untuk variabel keputusan berkunjung rata-rata total sebesar 3,59 hal ini menunjukkan bahwa keputusan yang dilakukan oleh wisatawan dalam menentukan lokasi wisatadi pulau Lombok adalah dengan memilih untuk mengunjungi Islamic center.

\subsection{Uji hipotesis}

Uji hipotesis pada penelitian ini terdiri dari uji $F$, uji $t$, dan adjusted $R^{2}$. Uji $F$ dilakukan untuk mengetahui kelayakan suatu model (Ferdinand, 2014).

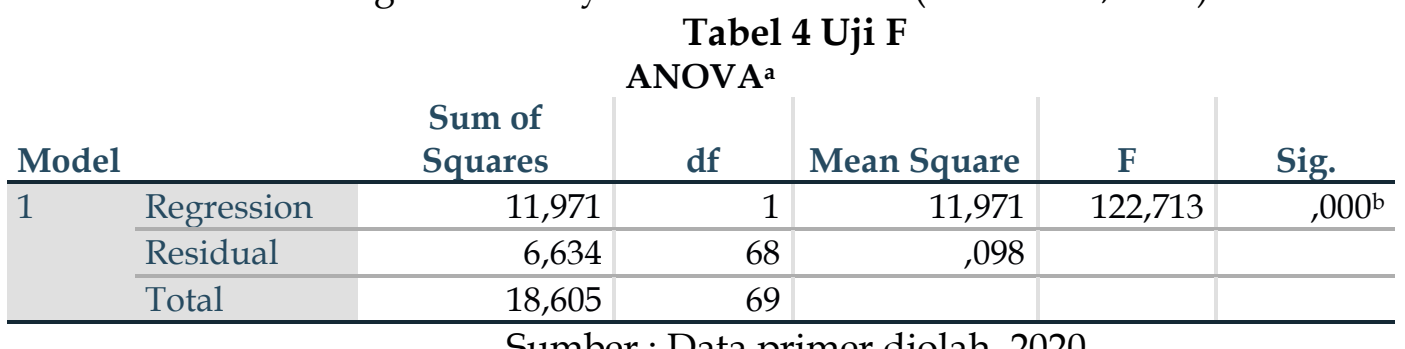

Sumber : Data primer diolah, 2020

Tabel 4menunjukkan nilai $\mathrm{F}$ hitung sebesar 122,713 atau lebih besar dari nilai $\mathrm{F}$ tabel (a:0,05;df1:2;df2:70) sebesar 3,13. Sehingga dapat diasumsikan bahwa semua variabel independen layak untuk menjelaskan variabel dependen yang dianalisis.

Uji hipotesis selanjutnya yaitu uji $t$ dilakukan untuk mengetahui seberapa jauh pengaruh satu variabel independen secara individual dalam menerangkan variabel dependen.

Tabel 5. Uji t.

Coefficients ${ }^{a}$

\begin{tabular}{|c|c|c|c|c|c|c|}
\hline & & $\begin{array}{l}\text { Uns } \\
\text { C }\end{array}$ & $\begin{array}{l}\text { ardized } \\
\text { cients }\end{array}$ & $\begin{array}{c}\text { Standardized } \\
\text { Coefficients }\end{array}$ & & \\
\hline & & B & Std. Error & & $t$ & Sig. \\
\hline & $\mathrm{n}$ tabel 5 & & & & & \\
\hline$\overline{1}$ & (Constant) &,- 306 & ,519 & &,- 589 & ,558 \\
\hline & Brand Image & ,953 & 126 & 676 & 7,573 & ,000 \\
\hline 2 & (Constant) &,- 694 & ,652 & & $-1,065$ & 291 \\
\hline & Brand Image & 786 & 211 & ,558 & 3,731 & ,000 \\
\hline & $\begin{array}{l}\text { Konsep wisata } \\
\text { halal }\end{array}$ & ,261 & ,265 & 147 & ,985 & ,328 \\
\hline
\end{tabular}

Sumber : Data primer diolah, 2020

Berdasarkan tabel 5menerangkan bahwa variabel konsep pariwisata halal berpengaruh positif sebesar 0,147 namun lebih rendah dari nilai signifikan yaitu sebesar 0,328 .

Uji hipotesis selanjutnya dalah uji Adjusted $\mathrm{R}^{2}$. UjiAdjustedR 2 digunakan untuk melihat seberapa besar variasi model pengaruh dari konsep wisata halal dan brand image terhadap keputusan berkunjung ke Islamic center.Hasil uji AdjustedR ${ }^{2}$ dapat dilihat di bawah ini.

Tabel 6. Koefisien determinasi

\begin{tabular}{ccc}
\hline Nomor & Model & R Square \\
\hline 1. & 1 & $0,465^{\mathrm{a}}$ \\
\hline 2. & 2 & $0,643^{\mathrm{b}}$ \\
\hline
\end{tabular}

Sumber : Data primer diolah, 2020 
Total keragaman data yang dapat dijelaskan oleh model penelitian adalah :

$\mathrm{R}^{2}=1-\left(\mathrm{R}_{1}^{2}\right) \cdot\left(\mathrm{R}_{2}^{2}\right)$

$\mathrm{R}^{2}=1-\left(0,465^{2}\right) *\left(0,643^{2}\right)$

$\mathrm{R}^{2}=1-0,216^{*} 0,412$

$\mathrm{R}^{2}=1-0,089$

$\mathrm{R}^{2}=0,911$

Berdasarkan hasil koefisien determinasi total sebesar 0,911 artinya keragaman data yang dapat dijelaskan oleh model penelitian ini adalah sebesar 91,1\%. Sedangkan sisanya dijelaskan oleh variabel yang lain dari luar model yang tidak dimasukkan ke dalam model penelitian ini.Hal ini menunjukkan bahwa kemampuan variabel bebas dalam menjelaskan varians dari variabel terikatnya adalah sebesar $91,1 \%$ berarti terdapat 9,9\% $(100 \%-91,1 \%)$ varians variabel terikat yang dijelaskan oleh faktor lain.Hal ini juga berarti bahwa nilai koefisien 0.911 menunjukkan adanya hubungan antar variabel independen dan variabel dependen yang sangat kuat.

\section{Pengaruh konsep pariwisata halal terhadap brand image}

Hasil penelitian menunjukkan bahwa konsep wisata halal berpengaruh positif dan signifikan terhadap keptusan berkunjung wisatawan ke objek wisataIslamic center.Penerapan konsep pariwisata halal terhadap suatu pulau dengan mayoritas muslim akan berpengaruh terhadap brand image, karena tidak menutup kemungkinan bahwa wisatawan yang mengunjungi daerah tersebut melihat profil dari pulau itu sendiri apalagi pulau Lombok dikenal sebagai pulau seribu masjid yang sangat menarik untuk dikunjugi. Hasil penelitian ini sejalan dengan hasil penelitian dari Haidar (2018) dan Sudigdo (2018) yang menujukkan bahwa adanya korelasi yang signifikan dan positif antara konsep pariwisata halal terhadap brand image pulau dengan mayoritas muslim. Neumeier (2003) mengatakan bahwa suatu produk akan mempunyai perbedaan dengan pesaingnya jika memiliki brand yang kuat, sehingga sebuah brand bisa dengan mudah dibedakan dari brand merk lain dan adanya branding dapat membentuk persepsi seseorang terhadap suatu produk tersebut sehingga dapat meningkatkan daya tarik.

\section{Pengaruh brand image terhadap keputusan berkunjung wisatawan}

Hasil penelitian menunjukkan bahwa brand image berpengaruh positif dan signifikan terhadap keputusan berkunjung wisatawan ke objek wisata Islamic center.Penerapan island branding pada suatu destinasi wisata akan berpengaruh terhadap keputusan wisatawan untuk mengunjungi suatu obyek wisata di daerah tersebut. Pulau yang sudah memiliki branding atau merek akan memiliki citra tersendiri bagi wisatawan karena memiliki ciri khas yang membedakan dengan pulau-pulau lain sehingga memberikan kenangan yang berbeda.

Hasil penelitianini sejalan dengan hasil penelitian yang dilakukan oleh Purwanto dan Soliha (2017) yang menyimpulkan bahwa brand image mempunyai pengaruh yang signifikan terhadap keputusan berkunjung. Selain itu, penelitian yang dilakukan oleh Putra (2017), Arif dan Gunadi (2018) dan Fitriana (2019) juga menunjukkan hal yang sama, bahwa brand image berpengaruh signifikan terhadap keputusan berkunjung.

Kotler (2009) dan Setiadi (2003) mengatakan bahwa adanya branding suatu produk dapat berfungsi sebagai pembeda dimanajika suatu produk memiliki branding yang kuat akan mudah dibedakan dengan kompetitor. Adanya branding yang dimiliki suatu produk dapat meningkatkan kepercayaan, pemberi keyakinan serta jaminan dan kualitas artinya dalam penelitian ini bahwa pulau Lombok dengan branding yang dimilikinya dapat dengan mudah dibedakan dengan destinasi-destinasi lainnya. Selain itu juga adanya 
branding yang kuat maka promosi akan mudah dilakukan, wisatawan cendrung memilih brand yang kuat dan loyal terhadap brand yang sama.

\section{Pengaruh konsep wisata halal terhadap keputusan berkunjung}

Hasil penelitian ini menunjukkan bahwa konsep wisata halal berpengaruh positif tetapi tidak signifikan terhadap keputusan berkunjung wisatawan.Dari hasil olah data menunjukkan bahwa nilai koefisien pengaruh sebesar 0,147 yang menunjukkan bahwa konsep pariwisata halal berpengaruh positif terhadap keputusan berkunjung. Namun nilai signifikansi lebih besar dari nilai cut off value 0,05 , sehingga dapat disimpulkan bahwa konsep pariwisata halal berpengaruh positif tetapi tidak signifikan terhadap keptusan berkunjung wisatawan ke Islamic center.

Hasil penelitian ini sejalan dengan penelitian yang dilakukan oleh Ma'rifah (2019)yang mengatakan bahwa halal tourism berpengaruh positif tetapi tidak signifikan terhadap keputusan berkunjung wisatawan. Menurut Fransisca (2019) penerapan konsep pariwisata halal di pulau Lombok berpengaruh pada keputusan berkunjung tetapi tingkat kesadaran masyarakat wisatawan muslim milenial domestic dalam mengunjungi destinasi wisata halal bertaraf Internasional sangat rendah, selain itu juga wisatawan Muslim milenial domestik masih lebih tertarik kepada faktor ketenangan yang bebas di tempat wisata, makanan dan minuman yang enak, pemandangan alam yang indah, dan penataan tempat wisata yang menarik sehingga dapat dibagikan kepada masyarakat luas di media sosial sebagai faktor yang lebih utama dalam mengambil keputusan mengunjungi tempat wisata.

\section{KESIMPULAN DAN SARAN}

\subsection{Kesimpulan}

Dari pembahasaan di atas, maka dapat berikan kesimpulan dari penelitian ini yang dapat diambil, yaitu :

(1) Konsep wisata halal berpengaruh positif dan signifikan terhadap brand image pulau Lombok artinya penerapan konsep pariwisata halal terhadap suatu pulau dengan mayoritas muslim akan berpengaruh terhadap brand image, hal ini dikarenakan bahwa wisatawan yang mengunjungi daerah tersebut melihat profil dari pulau itu sendiri apalagi pulau Lombok dikenal sebagai pulau seribu masjid yang sangat menarik untuk dikunjungi.

(2) Brand imageberpengaruh positif dan signifikan terhadap keputusan berkunjung wisatawan. Hal ini menunjukkan bahwa penerapan island branding pada suatu destinasi wisata akan berpengaruh terhadap keputusan wisatawan untuk mengunjungi suatu obyek wisata di daerah tersebut. Pulau yang sudah memiliki branding atau merek akan memiliki citra tersendiri bagi wisatawan karena memiliki ciri khas yang membedakan dengan pulau-pulau lain sehingga memberikan kenangan yang berbeda.

(3) Konsep wisata halal berpengaruh positif tetapi tidak signifikan terhadap keputusan berkunjung wisatawan artinya konsep wisata yang disesuaikan dengan prinsip syariah yaitu prinsip-prinsip ajaran Islam sangat baik dari segi amenities (fasilitas/sarana pendukung), aksesibility (sarana menuju objek wisata Islamic center) dan atraksi (atraksi wisata) sudah baik. Penerapan konsep pariwisata halal di pulau Lombok khususnya di Islamic centermemiliki batasan-batasan tertentu yang mengakibatkan wisatawan juga memiliki batasan prilaku tersendiri dalam mengunjungi objek wisata Islamic center tersebut. 


\subsection{Saran}

Salah satu hasil penelitian menunjukkan bahwa konsep pariwisata halal memperkuat brand image pulau Lombok sebagai pulau seribu masjid yang berdampak terhadap keputusan berkunjung wisatawan milenial, mengapa demikian?. Bagi peneliti berikutnya yang tertarik melakukan penelitian dengan variabel yang sama sangat disarankan untuk melakukan penelitian terkait temuan terbaru ini. Selain itu juga peneliti berikutnya perlu menambahkan variabel lainnya sebagai variabel yang dapat mempengaruhi keputusan berkunjung.Disamping itu, setiap item variabel yang ditetapkan oleh peneliti baru bersumber dari satu pengarang saja, bagi peneliti selanjutnya sebaiknya menghimpun indikator variabel yang lebih bervariasi.Hal ini perlu dilakukan agar para peneliti selanjutnya dapat menemukan hasil penelitian yang lebih variatif dan lebih baik bila dibandingkan dengan penelitian yang sekarang.Masjid Islamic Center Mataram merupakan ikon pulau Lombok dan dinobatkan sebagai masjid terbaik tingkat nasional tahun 2020.Dengan adanya prestasi tersebut, pihak pengelola harus mampu menjaga amanah yang telah dititipkan dari masyarakat maupun wisatawan agar dapat menciptakan sustainable tourism.

\section{DAFTAR PUSTAKA}

Anholt, Simon.2007. Competitive Identity: The New Brand Management for Nations, Citiesand Regions.USA:Palgrave Macmillan.

Arif, Gunadi. 2018. Pengaruh Citra merek Dan Kualitas Produk Terhadap Keputusan Berkunjung Ke Resto Foresthree. Fakultas Pariwisata Universitas Pancasila.

Adinugraha, Sartika, Kadarningsih. 2018. Desa Wisata Halal: Konsep Dan Implementasinya Di Indonesia. Universitas Dian Nuswantoro Semarang. Jawa Tengah.

Battour, M., \& Ismail, M. N. 2015. Halal tourism: Concepts, practises, challenges and future. Tourism Management Perspectives, Elsevier Ltd.

Battour, M, dan Ismail, M. N. 2016. Halal Tourism: Concepts, Practises, Challenges and Future. Tourism Management Perspective. 19: 150-154

Chookaew, S., Chanin, O., Charatarawat, J., Sriprasert, P, dan Nimpaya, S. 2015. Increasing Halal Tourism Potential at Andaman Gulf in Thailand for Muslim Country. Journal of Economics, Business and Management. 3(7): 739-741.

Cook et al., 2018. Tourism The Business Of Hospitality And Travel. Sixth Edition. 42.

Djakfar, Muhammad. 2019. Pariwisata Halal : Perspektif Multidimensi, Peta Jalan Meuju Pengembangan Akademik \& Industry Halal di Indonesia. UIN-Maliki Press.

Ferdinand, Augusty, 2014. Metode Penelitian Manajemen. BP Universitas Diponegoro. Semarang.

Fitriana. 2019. Pengaruh City Branding, Destination Image Dan Electronic Word Of Mouth Terhadap Keputusan Berkunjung Ke Wisata Halal Aceh. Fakultas Ekonomi Dan Bisnis Universitas Mercubuana Jakarta.

Fransisca, Yuniati dan Kurniawan A. 2019. Factors affecting the purchasing decision of the Millennial Muslim Generation: A review of personality destination, brand attractiveness, and brand awareness. Universitas Nurtanio.

Hadinoto, Kusudianto. 1996. Perencanaan Pengembangan Destinasi Pariwisata. Jakarta: UI Press.

Kotler, Philip. 2003. Marketing Management. New Jersey. Prentice Hall Jakarta.

Ma'rifah, Aula Nurul. 2020. Analisis Halal Tourism dan Aksesibilitas Terhadap Keputusan Wisatawan Berkunjung Pada Destinasi Wisata di Indonesia. UIN Raden Intan Lampung. 
Muharromah, Gabriele Lailatul dan Anwar, Moch. Khairul. 2020. Pengaruh Atraksi Wisata, Amenitas dan Aksesibilitas Terhadap Keputusan Berkunjung Pada Objek Wisata Religi Makam Kh. Abdurrahman Wahid. Fakultas Ekonomi. Universitas Negri Surabaya.

Mohsin, et al. 2016. Tourism Manajemen Perspectives. Halal Tourism: Emerging Opportunities.

Nasrullah, Muhammad dan Ardelia. 2015. Pengaruh Religiusitas dan Keputusan Konsumen Ter Hadap Produk. Jurnal Hokum Islam (JHI). Vol. 13 No 2 Desember 2015. Pekalongan: STAIN Pekalongan.

Safira, et al. 2019. Promosi Daerah Dan E-Marketing Pariwisata Halal Terhadap Keputusan Berkunjung Wisatawan Di Yogyakarta. Universitas Alma Ata, Yogyakarta, Indonesia.

Sudigdo, Agus. 2018. Dampak Fasilitas Ibadah, Makanan Halal, Dan Moralitas Islam Terhadap Keputusan Berkunjung Yang Dimediasi Citra Destinasi Wisata. Sekolah Tinggi Ilmu Ekonomi IPWI Jakarta.

Satriana dan Fridah. 2018. Wisata Halal: Pengembangan, Peluang dan Tantangan.Fakultas Ekonomi dan Manajemen, Sekolah Pascasarjana IPB.

Spillane, James J.1997. Pariwisata Indonesia. Kanisiua. Yogyakarta.

Yoeti, Oka A, 2008. Perencanaan dan Pengembangan Pariwisata. Pradnya Paramita: Jakarta. 